\title{
HUBUNGAN PENGETAHUAN TENTANG MENSTRUASI DENGAN KESIAPAN SISWI SD DALAM MENGHADAPI MENARCHE
}

\author{
Ida Nurmawati ${ }^{1}$, Feby Erawantini ${ }^{2}$ \\ ${ }^{1,2}$ Program Studi Rekam Medis, Jurusan Kesehatan, Politeknik Negeri Jember, \\ Jawa Timur, Indonesia \\ Email : ${ }^{1}$ Ida@ polije.ac.id ${ }^{2}$ feby_era@yahoo.co.id
}

Tanggal Submisi: 19 Oktober 2017; Tanggal Penerimaan: 31 Desember 2019

\begin{abstract}
ABSTRAK
Saat ini usia menstruasi pertama kali pada remaja putri terjadi lebih cepat dengan tidak diikuti kesiapan remaja dalam menghadapi menarche. Sehingga remaja memiliki respon negatif terhadap menarche yang dialaminya seperti merasa takut, terkejut, sedih, kecewa, malu, khawatir, dan bingung. Hasil survey SDKI tahun 2012 menyarankan remaja perlu dibekali informasi yang cukup menjelang haid pertamanya (menarche). Penelitian ini bertujuan untuk mengetahui hubungan tingkat pengetahuan siswi SD tentang menstruasi dengan kesiapan siswi SD dalam menghadapi menarche. Jenis penelitian bersifat observatiobal study dengan pendekatan crossectional. Populasi dalam penelitian ini adalah siswi kelas 6 SDN Tegalgede 01 Kabupaten Jember berjumlah 37. Sampel dalam penelitian ini diambil dengan teknik sampling jenuh sehingga total sampel berjumlah 37 siswi. Analisis dalam penelitian ini menggunakan uji Rank Spearman. Analisis bivariat menggunakan tabel silang diketahui bahwa siswi dengan kesiapan baik lebih banyak terjadi pada siswi dengan pengetahuan baik $(82,4 \%)$ dibandingkan siswi dengan pengetahuan kurang (30\%). Hasil uji statistik didapatkan ada hubungan tingkat pengetauan siswi SD tentang menstruasi dengan kesiapan siswi dalam menghadapi menarche ( $\mathrm{p}$ value $=0,026$ ). Berdasarkan nilai $\mathrm{r}=0,367$ diketahui bahwa semakin tinggi tingkat pengetahuan maka semakin siap siswi dalam menghadapi menarche.
\end{abstract}

Kata kunci : menarche, menstruasi, kesiapan remaja

ISSN 1979-7621 (Print). ISSN 2620-7761 (Online).

\begin{abstract}
Currently, the first menstrual period in young women occurs faster without readiness in facing menarche. So that adolescents have a negative response to menarche experienced such as fear, shock, sad, disappointed, embarrassed, worried, and confused. The result of the survey of SDKI in 2012 suggested that adolescents need to be provided with enough information before menarche. This study aims to determine the relationship of knowledge about menstruation with the readiness of elementary school students in facing menarche. The type of research is observatiobal study with crossectional approach. The population in this study were 6th grade students of SDN Tegalgede 01 Kabupaten Jember totaling
\end{abstract}


37. The samples in this study were taken with a sampling technique saturated so that the total sample amounted to 37 female students. Analysis in this research use Rank Spearman test. The bivariate analysis using crosstabulation shows that students with good readiness are more happening to students with good knowledge $(82,4 \%)$ than students with less knowledge $(30 \%)$. The result of statistical test showed that there was a relationship between the knowledge about menstruation with the readiness of female students in facing menarche ( $\mathrm{p}$ value $=$ $0,026)$. Based on the value $r=0.367$ note that the higher the level of knowledge the more ready for students in facing menarche.

Keywords : menarche, menstruation, adolescent readiness

\section{PENDAHULUAN}

Adolescent (Remaja) merupakan penduduk dalam rentang usia 10-18 tahun, dimana dalam masa tersebut terjadi perkembangan psikologis dan pola identifikasi dari anak-anak menjadi dewasa. Peralihan perkembangan anak menjadi dewasa ditandai dengan perubahan hormonal, fisik, psikologis, maupun sosial yang berlangsung secara sekuensial (Batubara, 2010). Remaja memiliki sifat khas berupa rasa keingintahuan yang besar dan cenderung berani mengambil risiko tanpa didahului dengan pertimbangan yang matang. Hal tersebut memungkinkan remaja salah dalam mengambil keputusan yang menyebabkan remaja memiliki perilaku berisiko berkaitan kesehatan reproduksi remaja (Path Kesehatan Reproduksi Remaja dan Kemenkes).

Kesehatan reproduksi merupakan keadaan sehat secara fisik, mental, dan sosial secara utuh, tidak semata-mata bebas dari penyakit atau kecatatan yang berkaitan dengan sistem, fungsi, dan proses reproduksi pada laki-laki dan perempuan (Kementrian Hukum dan HAM RI, 2014). Salah satu masalah kesehatan reproduksi remaja, khususnya remaja putri adalah menarche atau menstruasi pertama kali. Akhir-akhir ini usia menstruasi pertama kali pada remaja putri terjadi lebih cepat. Penelitian yang dilakukan di Kabupaten Pati diketahui jika rata-rata perempuan mengalami menstruasi pertama kali pada usia 12,2 tahun, sedangkan penelitian di Bogor diketahui rata-rata usia menarche adalah 10,3 tahun (Amaliah dkk, 2012). Hasil Riskesdas tahun 2010 menunjukkan bahwa rata-rata usia menarche di Indonesia adalah usia 13 tahun sebesar $20 \%$, dengan kejadian lebih awal yaitu usia 9-11 tahun sebesar 5,2\% (Balitbangkes, 2010). Sementara itu menurut penelitian Aboyeji et all tahun 2005 diperoleh hasil bahwa remaja memiliki respon negatif terhadap menarche yang dialaminya seperti merasa takut, terkejut, sedih, kecewa, malu, khawatir, dan bingung (Fajri dan Khairani, 2010). Hasil survey SDKI tahun 2012 menyarankan remaja perlu dibekali informasi yang cukup menjelang haid pertamanya (menarche).

Pentingnya membekali remaja dengan informasi menjelang menarche ini terkait bahwa salah satu faktor yang memegang peranan penting dalam kesediaan atau kesiapan (sikap) menerima/melakukan sesuatu adalah pengetahuan (Fitriani, 2011). Hal ini sesuai dengan penelitian di Tidore Kepulauan bahwa ada hubungan pengetahuan dengan kesiapan remaja 
putri dalam menghadapi menarche (Yusuf dkk, 2014).

SDN Tegalgede 01 Kabupaten Jember merupakan salah satu SD negeri di Kabupaten Jember yang terletak di tengah kota berdekatan dengan Universitas Jember dan Politeknik Negeri Jember. Hal ini memungkinkan masyarakat, khususnya remaja sekitar mudah untuk akses informasi terkait informasi kesehatan. Berdasarkan studi pendahuluan diketahui bahwa SDN Tegalgede 01 pernah diberikan penyuluhan tentang menstruasi dan sebagian besar sisiwi telah mengetahui menstruasi namun belum bisa terbuka untuk bercerita tentang menstruasi. Dua siswi yang telah menstruasi malu ketika ditanya tentang pengalaman menstruasinya.

Berdasarkan uraian tersebut maka peneliti tertarik untuk melakukan penelitian tentang hubungan tingkat pengetahuan siswi SDN Tegalgede 01 dengan kesiapan siswi SD dalam menghadapi menarche.

\section{METODE PENELITIAN}

Jenis penelitian ini merupakan penelitian observational study dengan pendekatan crossectional dimana variabel pengetahuan dan kesiapan siswi SD dikumpulkan dalam satu waktu. Populasi dalam penelitian ini adalah siswi kelas 6 SDN Tegalgede 01 Kabupaten Jember sejumlah 37. Pengambilann sampel dalam penelitian ini menggunakan teknik sampling jenuh, dimana seluruh populasi menjadi sampel penelitian.

Variabel pengetahuan dan kesiapan siswi SD dikumpulkan dengan menggunakan kuesioner yang dibagikan kepada siswi SDN Tegalgede 01, dimana pengisian kuesioner dipandu oleh peneliti. Kuesioner berisikan 9 pertanyaan pengetahuan tentang menstruasi dan 11 pertanyaan untuk kesiapan menghadapi menstruasi.

Analisis univariat disajikan dalam tabel distribusi frekuensi yang bertujuan untuk mengetahui gambaran pengetahuan dan kesiapan siswi SDN Tegal gede 01 . Analisis bivariat disajikan dalam tabel silang untuk mengetahui hubungan pengetahuan dengan kesiapan siswi SD.

Analisis bivariat dalam penelitian ini menggunakan uji Rank Spearman karena data penelitian berdistribusi tidak normal. Pengambilan keputusan berdasarkan nilai $\mathrm{p}$, jika nilai $\mathrm{p}<0,05$ maka Ho ditolak Ha diterima artinya ada hubungan pengetahuan dengan kesiapan siswi SD. Jika nilai $\mathrm{p}>0,05$ maka Ho diterima Ha ditolak artinya tidak ada hubungan pengetahuan dengan kesiapan siswi SD. Selain itu pengambilan keputusan berdasarkan nilai koefisien korelasi $\left(\mathrm{r}_{\mathrm{s}}\right)$ untuk mengetahui kekuatan hubungan dan arah hubungan. Nilai $r_{s}$ mendekati nilai 1/-1 artinya korelasi/hubungan semakin kuat, nilai $r_{s}$ mendekati 0 artinya korelasi/hubungan semakin lemah. Nilai $r_{s}$ positif menunjukkan hubungan variabel dependent dan independent satu arah artinya kenaikan variabel independent akan diikuti kenaikan variabel dependent. Nilai rs negative maka arah hubungannya berlawanan arah atau kebalikan dari pola hubungan positif.

\section{HASIL DAN PEMBAHASAN}

Gambaran pengetahuan siswi SDN Tegalgede 01 dapat dilihat pada tabel 1. Tabel 1 menunjukkan bahwa pengetahuan kurang $(54,1 \%)$ lebih banyak dibandingkan pengetahuan baik $(45,9 \%)$. Ada beberapa poin pertanyaan yang dijawab responden tidak tepat seperti usia menarche, darah menstruasi 
banyak keluar, frekuensi mengganti pembalut, frekuensi menstruasi dalam satu bulan, dan ciri pubertas pada wanita. Hal tersebut dapat dilihat pada Tabel 2.

Tabel 1. Distribusi frekuensi pengetahuan responden tentang menstruasi

\begin{tabular}{lcc}
\hline Pengetahuan & Frekuensi & $\begin{array}{c}\text { Prosentase } \\
(\%)\end{array}$ \\
\hline Baik & 17 & 45,9 \\
Kurang & 20 & 54,1 \\
\hline Total & 37 & 100 \\
\hline
\end{tabular}

Berdasarkan Tabel 2 diketahui jika lebih dari setengah responden sudah menjawab dengan tepat dan sekitar sepertiga responden menjawab kurang tepat. Contohnya adalah sebesar $29,7 \%$ responden menjawab bahwa menstruasi merupakan tanda kelainan pada wanita dan sebesar 70,3\% menjawab menstruasi merupakan tanda pubertas pada wanita. Sebesar 24,3\% responden menjawab menstruasi terjadi 2 bulan sekali dan sebesar $75,7 \%$ menjawab menstruasi terjadi satu bulan sekali.

Tabel 3 menunjukkan hal yang berkenalikan dengan Tabel 1, dimana prosentase kesiapan siswi lebih banyak pada kategori baik sebesar 54,1\% dibandingkan kategori kurang 45,9\%. Untuk lebih mengetahui gambaran kesiapan siswi SD, berikut uraian jawaban responden tentang ketidaksiapan menghadapi menarche dalam Tabel 4.

Pengetahuan merupakan salah satu faktor yang menentukan seseorang bersikap dalam hal ini sikap menerima/kesiapan menghadapi menarche (Fitriani, 2011). Gambaran kesiapan menghadapi menarche dapat dilihat pada Tabel 3.

Berdasarkan Tabel 4 dapat diketahui bahwa sebesar $40,5 \%$ siswi tidak menunggu datangnya menstruasi dan merasa takut menghadapi menstruasi serta sebesar 45,9\% bingung jika menstruasi itu datang. Sebesar 59,5\% siswi menganggap bahwa menstruasi tidak perlu diceritakan kepada orang lain namun sebesar $83,8 \%$ akan menceritakan kepada orangtua/saudara/dokter jika terjadi kelainan saat menstruasi serta sebesar $73 \%$ akan mencari sebanyakbanyaknya informasi tentang menstruasi jika suatu saat mereka mengalami menstruasi. Lebih dari duapertiga $(67,6 \%)$ siswi setuju bahwa menstruasi akan mengakibatkan ketidaknyamanan fisik dan gangguan emosional, hal ini menunjukkan bahwa siswi tahu konsekuensi dari terjadinya menstruasi. Pemahaman siswi tersebut dapat mengindikasikan penerimaan terhadap ketidaknyamanan saat wanita sedang menstruasi.

Tabel 2. Distribusi frekuensi jawaban responden tentang pengetahuan menstruasi

\begin{tabular}{lcccc}
\hline \multicolumn{2}{c}{ Pengetahuan } & \multicolumn{2}{c}{ Benar } & \multicolumn{2}{c}{ Salah } \\
\cline { 2 - 5 } & $\mathrm{f}$ & $\%$ & $\mathrm{f}$ & $\%$ \\
\hline Menstruasi pertma & 25 & 67, & 1 & 32, \\
kali & & 6 & 2 & 4 \\
$\begin{array}{l}\text { Darah menstruasi } \\
\text { banyak keluar pada }\end{array}$ & 26 & 70, & 1 & 29, \\
hari & & 3 & 1 & 7 \\
$\begin{array}{l}\text { Frekuensi } \\
\text { penggantian }\end{array}$ & 29 & 78, & 8 & 21, \\
pembalut & & 4 & & 6 \\
Frekuensi menstruasi & 28 & 75, & 9 & 24, \\
& & 7 & & 3 \\
Menstruasi & 26 & 70, & 1 & 29, \\
merupakan tanda & & 3 & 1 & 7 \\
\hline
\end{tabular}

Tabel 3. Distribusi frekuensi Kesiapan menghadapi menarche

\begin{tabular}{lcc}
\hline Kesiapan & Frekuensi & $\begin{array}{c}\text { Prosentase } \\
(\%)\end{array}$ \\
\hline Baik & 20 & 54,1 \\
Kurang & 17 & 45,9 \\
\hline Total & 37 & 100 \\
\hline
\end{tabular}


Hasil penelitian pada tabel 1 dan tabel 3 tidak menunjukkan konsistensi, dimana dari tabel 1 diperoleh informasi bahwa responden lebih banyak yang berpengetahuan kurang $(54,1)$, namun pada tabel 3 diperoleh informasi responden lebih banyak memiliki kesiapan yang baik. Pengetahuan merupakan salah satu faktor penentu sikap seseorang (Fitriani, 2011 dan Notoadmodjo, 2003).

Salah satu faktor yang mempengaruhi proses belajar yang efektif adalah instrumental. Instrumental harus dirancang dengan memperhatikan materi dan subjek belajar (sasaran). Metode untuk belajar pengetahuan lebih baik menggunakan metode ceramah, sedangkan metode untuk belajar sikap, keterampilan atau perilaku lebih baik digunakan demonstrasi, bermain peran, atau permainan. Selain pemilihan metode pembelajaran yang tepat, pemilihan media pembelajaran yang tepat juga dapat membantu penyampaian informasi dan kejelasan informasi (Notoatmojo, 2003).

Distribusi frekuensi pada tabel 5 memberikan informasi lebih rinci dibandingkan tabel 1 dan tabel 3. Jika informasi hanya diperoleh pada tabel 1 dan 3 maka hasilnya tidak konsistem karena siswi banyak berpengetahuan kurang namun memiliki kesiapan yang baik. Hal ini dapat diperjelas pada tabel 5.

Tabel 5 menunjukkan bahwa kesiapan yang baik pada siswi SD banyak terjadi pada siswi dengan pengetahuan baik sebesar $82,4 \%$ dibandingkan siswi dengan pengetahuan kurang sebesar $30 \%$. Hal ini menunjukkan bahwa pengetahuan berperan dalam pembentukan sikap siswi kaitannya dengan kesiapan siswi dalam menghadapi menarche (Notoatmodjo, 2003)
Tabel 4. Distribusi frekuensi jawaban responden tentang kesiapan menghadapi

\begin{tabular}{|c|c|c|c|c|}
\hline \multirow[t]{2}{*}{ Kesiapan } & \multicolumn{2}{|c|}{ Setuju } & \multicolumn{2}{|c|}{$\begin{array}{l}\text { Tidak } \\
\text { Setuju }\end{array}$} \\
\hline & $\mathrm{F}$ & $\%$ & $f$ & $\%$ \\
\hline $\begin{array}{l}\text { Saya menunggu } \\
\text { menstruasi pertama kali }\end{array}$ & 15 & 40,5 & 22 & 59,5 \\
\hline $\begin{array}{l}\text { Saya takut menghadapi } \\
\text { menstruasi pertama kali }\end{array}$ & 15 & 40,5 & 22 & 59,5 \\
\hline $\begin{array}{l}\text { Saya bingung } \\
\text { menghadapi menstruasi } \\
\text { pertama kali }\end{array}$ & 17 & 45,9 & 20 & 54,1 \\
\hline $\begin{array}{l}\text { Saya menganggap } \\
\text { menstruasi hal yang tabu } \\
\text { sehingga tidak perlu } \\
\text { diceritakan kepada orang } \\
\text { laun }\end{array}$ & 22 & 59,5 & 15 & 40,5 \\
\hline $\begin{array}{l}\text { Mentruasi akan } \\
\text { menyebabkan } \\
\text { ketidaknyamanan fisik } \\
\text { dan perubahan emosional } \\
\text { diri saya }\end{array}$ & 25 & 67,6 & 12 & 32,4 \\
\hline $\begin{array}{l}\text { Saya menganggap } \\
\text { menstruasi sebagai suatu } \\
\text { hal yang merepotkan } \\
\text { karena harus membawa } \\
\text { dan mengganti pembalut }\end{array}$ & 20 & 54,1 & 17 & 45,9 \\
\hline $\begin{array}{l}\text { Saya menganggap } \\
\text { menstruasi sebagai suatu } \\
\text { yang kotor }\end{array}$ & 15 & 40,5 & 22 & 59,5 \\
\hline $\begin{array}{l}\text { Saya akan mencari } \\
\text { sebanyak-banyaknya jika } \\
\text { menstruasi datang }\end{array}$ & 27 & 73 & 10 & 27 \\
\hline $\begin{array}{l}\text { Jika saat menstruasi ada } \\
\text { tanda-tanda kelainan } \\
\text { maka saya akan } \\
\text { menceritakan kepada } \\
\text { orangtua/saudara/dokter }\end{array}$ & 31 & 83,8 & 6 & 16,2 \\
\hline
\end{tabular}

Gambaran hubungan pengetahuan dan kesiapan menghadapi menarche dapat terlihat jelas pada Tabel 5 .

Tabel 5. Distribusi frekuensi hubungan pengetahuan dengan kesiapan menghadapi menarche

\begin{tabular}{|c|c|c|c|c|c|}
\hline \multirow[t]{3}{*}{ Pengetahuan } & \multicolumn{4}{|c|}{ Kesiapan } & \multirow[t]{3}{*}{ Total } \\
\hline & \multicolumn{2}{|c|}{ Baik } & \multicolumn{2}{|c|}{ Kurang } & \\
\hline & $\mathbf{f}$ & $\%$ & $\mathbf{f}$ & $\%$ & \\
\hline Baik & 14 & 82,4 & 3 & 17,6 & 100 \\
\hline Kurang & 6 & 30 & 14 & 70 & 100 \\
\hline
\end{tabular}


Hubungan pengetahuan dan kesiapan siswi SD dapat memiliki makna dengan melihat hasil uji statsitik. Uji statistik menggunakan Rank Spearman test yang digambarkan pada tabel 6 .

\section{Tabel 6 Hasil uji Rank Spearman}

\begin{tabular}{|c|c|c|c|}
\hline $\begin{array}{c}\text { Variabel } \\
\text { Penelitian } \\
\end{array}$ & $r_{s}$ & $\begin{array}{c}\mathrm{P} \\
\text { value }\end{array}$ & Keterangan \\
\hline $\begin{array}{l}\text { Pengetahuan } \\
\text { Sikap }\end{array}$ & 0,367 & 0,026 & $\begin{array}{ll}- & \text { Ada } \\
& \text { hubungan } \\
- & \text { korelasi } \\
& \text { lemah } \\
- & \text { arah } \\
& \text { hubungan } \\
\text { positif }\end{array}$ \\
\hline
\end{tabular}

Berdasarkan Tabel 6 diketahui bahwa ada hubungan tingkat pengetahuan dan kesiapan siswi dalam menghadapi menarche $(\mathrm{p}$ value $=0,026)$. Nilai koefisien korelasi spearman $\left(r_{s}\right)=0,367$ dapat digunakan untuk mengetahui kekuatan hubungan dan arah hubungan. Nilai $\mathrm{r}_{\mathrm{s}}=0,367$ menunjukkan korelasi/hubungan yang lemah karena nilai $r_{s}$ mendekati 0 . Namun meskipun hubungannya lemah, pola hubungan yang terbentuk adalah pola hubungan positif atau satu arah artinya peningkatan pengetahuan dapat menyebabkan peningkatan kesiapan siswi dalam menghadapi menarche.

Hasil penelitian ini sesuai dengan penelitian di Yogyakarta dimana ada hubungan pengetahuan dengan kesiapan menghadapi menstruasi ( $\mathrm{p}$ value $=0,000$ ) dan koefisien korelasi 0,573 (Dewi dan Khusnal, 2017).

\section{KESIMPULAN}

Siswi dengan pengetahuan kurang $(54,1 \%)$ lebih banyak dibandingkan pengetahuan baik $(45,9 \%)$. Siswi dengan kesiapan yang baik lebih banyak $(54,1 \%)$ lebih banyak dibandingkan kesiapan kurang (45,9\%). Siswi dengan kesiapan yang baik banyak terjadi pada siswi dengan pengetahuan baik $(82,4 \%)$ dibandingkan siswi dengan pengetahuan kurang (30\%). Ada hubungan tingkat pengetahuan dengan kesiapan menghadapi menarche ( $\mathrm{p}$ value $=0,026$ ), dimana korelasi yang terbentuk adalah korelasi lemah namun memiliki pola hubungan positif. Artinya jika ingin meningkatkan kesiapan siswi dalam menghadapi menarche maka perlu dilakukan peningkatan pengetahuan melalui pemberian informasi pada siswi SD atau remaja usia menarche. Pemberian informasi kepada siswi SD tentang menarche lebih tepat mengkombinasikan antara metode ceramah dan demosntrasi (simulasi) yang disertai dengan alat peraga.

\section{DAFTAR PUSTAKA}

Amaliah, N., Sari, K. \& Rosha, B. C. (2012). Status Tinggi Badan Pendek Berisiko Terhadap Keterlambatan Usia Menarche Pada Perempuan Remaja Usia 10-15 Tahun (Stunting Increased Risk Of Delaying Menarche On Female Adolescent Aged 10-15 Years). Penel Gizi Makan, 35 (2), 150-158.

Balitbangkes. (2010). Riset Kesehatan Dasar. Badan Penelitian dan Pengembangan Kesehatan Kementerian Kesehatan RI, Jakarta.

Batubara, J. R. (2010). Adolescent Development (Perkembangan Remaja). Sari Pediatri, Vol. 12 No. 1. 
Dewi, C. F. \& Khusnal, E. (2017). Hubungan Pengetahuan Dengan Kesiapan Menghadapi Menstruasi Pada Siswi Kelas 5 di SD Muhammadiyah Wirobrajan 3 Yogyakarta. Universitas 'Aisyiyah Yogyakarta, Yogyakarta, 2017.

Fajri, A. \& Khairani, M. (2010). Hubungan Antara Komunikasi Ibu-Anak Dengan Kesiapan Menghadapi Menstruasi Pertama (Menarche) Pada Siswi SMP Muhammadiyah Banda Aceh. Universitas Diponegoro, Semarang.

Fitriani, S. (2011). Promosi Kesehatan. Graha Ilmu, Yogyakarta.

Kemenkes Infodatin : Situasi Kesehatan Reproduksi Remaja. Pusat Data dan Informasi, Kementerian Kesehatan RI, Jakarta.

Notoatmodjo, S. (2003). Pendidikan dan Perilaku Kesehatan. Rineka Cipta, Jakarta.

Path Kesehatan Reproduksi Remaja. (2000) Membangun Perubahan Yang Bermakna. OutLook, Vol 16.

Peraturan Pemerintah Republik Indonesia Nomor 61 Tahun 2014 Tentang Kesehatan Reproduksi. Kementerian Hukum dan HAM RI, City, 2014.

Survei Demografi dan Kesehatan Indonesia 2012. (2013). Kesehatan Reproduksi Remaja. Badan Kependudukan dan Keluarga Berencana Nasional, Badan Pusat Statistik, Kementerian Kesehatan, Measure DHS ICF Internasional, Jakarta.

Yusuf, Y., Kundre, R. \& Rompas, S. (2014). Hubungan Pengetahuan Menarche Dengan Kesiapan Remaja Putri Menghadapi Menarche di SMP Negeri 3 Tidore Kepulauan. Universitas Sam Ratulangi, Manado. 